\title{
Multiuser Scheduling In 3GPP LTE-A Uplink Non- Stand-Alone Cellular Network With Virtual MIMO
}

Shweta Kukade ( $\sim$ kukadeshweta07@gmail.com )

College of Engineering Pune https://orcid.org/0000-0002-6729-1047

\section{S. Sutaone}

COEP, Pune

\section{R. A. Patil}

COEP, Pune

\section{Keywords:}

Posted Date: April 12th, 2021

DOI: https://doi.org/10.21203/rs.3.rs-316201/v1

License: (c) (1) This work is licensed under a Creative Commons Attribution 4.0 International License. Read Full License 


\section{Abstract}

The authors have requested that this preprint be removed from Research Square. 